\title{
Kryzys imigracyjny w UE w latach 2015-2017. Aspekty prawne i polityczne
}

Jednym z najbardziej bolesnych problemów współczesnego świata jest ogromna liczba ludzi zmuszonych do opuszczenia swoich domów w następstwie wojen lub innych form przemocy, skrajnego ubóstwa bądź rozmaitych czynników losowych. Raport Wysokiego Komisarza Narodów Zjednoczonych ds. Uchodźców (UNHCR) za rok 2016 podawał, że liczba takich osób wyniosła w skali świata aż 65,6 mln, z czego wyraźną większość, tzn. 40,3 mln stanowili tzw. uchodźcy wewnętrzni, pozostali natomiast opuścili swoje kraje pochodzenia. Najwięcej spośród nich pochodziło z Syrii, Afganistanu i Sudanu Południowego. Uciekinierzy znajdowali schronienie przede wszystkim w Turcji, Pakistanie, Libanie, Iranie, Ugandzie i Etiopii (Global Trends).

Wydarzenia Arabskiej Wiosny, zwłaszcza wojna domowa w Syrii, w połączeniu z szeregiem problemów demograficznych, ekonomicznych, zmian klimatycznych, etc., spowodowały z początkiem drugiej dekady XXI wieku nasilenie presji migracyjnej na Europę. Z jej najbliższego sąsiedztwa, tj. Bliskiego Wschodu i Afryki, zaczęły napływać setki przybyszów, szukających lepszego życia na Starym Kontynencie, postrzeganym przez nich jako oaza bezpieczeństwa i dobrobytu. Dwa główne szlaki prowadziły z Libii przez Morze Śródziemne do Włoch oraz z Syrii przez Turcję do Grecji. Imigranci przybywający do Europy kierowali się zarówno pobudkami ekonomicznymi, jak i ucieczką przed wojną i prześladowaniami. Opinia publiczna podchwyciła publicystyczny termin „uchodźcy”, jakim owi przybysze zostali obdarzeni, niemniej jednak biorąc pod uwagę, że z prawnego punktu widzenia uchodźcą staje się dopiero osoba, która taki status otrzymała w oparciu o prawo międzynarodowe i przepisy wewnętrzne, w dbałości o precyzję języka w niniejszym opracowaniu autor unika tego określenia, posługując się najczęściej terminem ,imigranci”. Celem artykułu jest omówienie problemu imigracyjnego od 2015 r. do połowy 2017 r., odtworzenie najistotniejszych decyzji UE na temat relokacji osób ubiegających się o ochronę międzynarodową, sporów jakie tej kwestii towarzyszyły na arenie europejskiej i sformułowanie rekomendacji dla polityki UE.

\section{Konwencja genewska o uchodźcach - prawny fundament polityki azylowej}

Najważniejszą prawnomiędzynarodową podstawą ochrony uchodźców pozostaje Konwencja genewska dotycząca statusu uchodźców z 28 lipca 1951 r., uzupełniona Protokołem nowojorskim z 31 stycznia 1967 r. (Protokót dotyczacy, 1991). Wyjaśniając termin „uchodźca” odwołuje się ona do kilku dokumentów z lat 1926-1939, zasadniczo definiując go jako osobę, która „na skutek uzasadnionej obawy przed prześladowaniem z powodu swojej rasy, religii, narodowości, przynależności do określonej grupy społecz- 
nej lub z powodu przekonań politycznych przebywa poza granicami państwa, którego jest obywatelem, i nie może lub nie chce $\mathrm{z}$ powodu tych obaw korzystać $\mathrm{z}$ ochrony tego państwa, albo która nie ma żadnego obywatelstwa i znajdując się, na skutek podobnych zdarzeń, poza państwem swego dawnego stałego zamieszkania nie może lub nie chce z powodu tych obaw powrócić do tego państwa" (art. 1 ust. 2). Konwencja wskazuje jednocześnie szereg wyłączeń ze statusu uchodźcy. W szczególności wyłączenie takie dotyczy osób, które popełniły najcięższe przestępstwa w rozumieniu międzynarodowego prawa humanitarnego, bądź inną poważną zbrodnię o charakterze innym niż polityczny (art. 1 ust. 6). Zastrzeżenie to może mieć szczególną wagę w kontekście konfliktu w Syrii, jako że pojawiały się poważne poszlaki wskazujące, że do Europy docierali także żołnierze armii syryjskiej podejrzani o udział w zbrodniach. Konwencja omawia również kwestie związane z zakwaterowaniem, zatrudnieniem, dostępem do sądów, opieką społeczna, pomocą administracyjna, wydawaniem dokumentów, przenoszeniem mienia itp. Co istotne, gwarantuje legalnie przebywającym w danym państwie uchodźcom swobodę poruszania się po jego terytorium (art. 26). Konwencja jednocześnie zakazuje dyskryminowania osób, które w sposób nielegalny dostały się na terytorium danego państwa bezpośrednio z obszaru zagrożenia, pod warunkiem zgłoszenia się do miejscowych władz. Nakłada również pewne ograniczenia w zakresie odsyłania uchodźców (art. 31-32). Szczególne znaczenie w kontekście ochrony międzynarodowej ma artykuł 33 konwencji, który wyraźnie zakazuje wydalania uchodźców do granic terytoriów, gdzie ich życie lub wolność byłyby zagrożone ze względów wymienionych w art. 1. Państwa pobytu powinny ułatwiać asymilację i naturalizację osób objętych statusem uchodźcy. W toku wykonywania swych obowiązków państwa powinny ściśle współpracować z Urzędem Wysokiego Komisarza Narodów Zjednoczonych do spraw Uchodźców (art. 34-35) (Konwencja dotyczaca, 1991).

W kontekście kryzysu migracyjnego w Europie, w obiegowej opinii mianem uchodźców zwykle obdarzane są wszystkie osoby, które dotarły do Starego Kontynentu (najczęściej do Grecji lub Włoch) z Azji lub Afryki, by ubiegać się o ochronę międzynarodowa, a tym samym znaleźć bezpieczną i dostatnią przyszłość. Zapisy konwencji genewskiej pozwalają jednak uściślić kryteria terminu uchodźca: przede wszystkim jest to ucieczka przed możliwymi prześladowaniami ze względu na takie cechy, jak rasa, religia, narodowość, przynależność do danej grupy społecznej, poglądy polityczne. Oprócz spełnienia którejś z powyższych przesłanek, w ścisłym znaczeniu zapisów konwencji warunkiem statusu uchodźcy jest też opuszczenie własnego kraju. Niemniej jednak w powszechnym ujęciu funkcjonuje też termin „uchodźcy wewnętrzni”, odnoszący się do osób, które uciekając przed możliwymi prześladowaniami pozostały na terytorium kraju pochodzenia. Zapisy konwencji natomiast nie traktują życia w skrajnej biedzie jako przesłanki uchodźstwa. Dlatego też rozważania wokół problematyki imigracyjnej wymagają rozróżniania pojęć takich jak uchodźcy i imigranci ekonomiczni.

\section{Europejskie podstawy polityki azylowej}

Istotne uregulowania dotyczące praw człowieka, w tym kwestii uchodźców, można odnaleźć także w skali regionalnej. Na Starym Kontynencie najważniejszym doku- 
mentem w tym zakresie pozostaje wciąż Konwencja o ochronie praw człowieka i podstawowych wolności z 1950 r. (Konwencja o ochronie, 1993). Uchodźcy nie są centralnym zagadnieniem Konwencji, niemniej jednak do interesującej nas problematyki można odnieść art. 4 Protokołu czwartego do Konwencji, ogłoszonego 16 września 1963 r. Składa się ona z krótkiego zapisu, zakładającego że „Zbiorowe wydalanie cudzoziemców jest zabronione" (Protokót czwarty, 1995). Zagadnienia te porusza także Protokół siódmy do Konwencji z 22 listopada 1984 r. Art. 1 Protokołu zakazuje wydalania legalnie przebywających $\mathrm{w}$ danym państwie cudzoziemców, $\mathrm{z}$ wyjątkiem wydalenia w oparciu o ustawę, przy czym przysługuje im możliwość przedstawienia swoich argumentów i złożenia odwołania przed stosownym organem. Pozycję państwa jednak umacnia dalszy zapis, który przewiduje możliwość wydalenia bez powyższych uprawnień ze względu na porząadek publiczny lub bezpieczeństwo państwa (Protokół $n r$ 7, 2003). Zapisy te są zbliżone do treści konwencji genewskiej.

W dorobku prawnym Unii Europejskiej zagadnienia azylowe i migracyjne zajmują obszerne miejsce. Od początku istnienia Unii, tj. od listopada 1993 r., kwestie te mieściły się w jej trzecim filarze, dotyczącym współpracy w zakresie wymiaru sprawiedliwości i spraw wewnętrznych. Na mocy traktatu amsterdamskiego z 1997 r., dokonano ich transferu do pierwszego filara. Po likwidacji trójfilarowej konstrukcji UE wraz z wejściem w życie traktatu lizbońskiego w grudniu 2009 r. omawiane zagadnienia znalazły się w tytule V części trzeciej Traktatu o Funkcjonowaniu Unii Europejskiej (TFUE), obejmującym Przestrzeń Wolności, Bezpieczeństwa i Sprawiedliwości (PWBiS) (TFUE, art. 67-80), w szczególności zaś w jego rozdziale drugim (art. 77-80), zatytułowanym Polityki dotyczące kontroli granicznej, azylu i imigracji.

Także w prawie pochodnym UE problematyka azylu i imigracji zajmuje obszerne miejsce. Interesujące nas zagadnienia, składające się na tzw. Wspólny Europejski System Azylowy, mieszczą się w kilku kluczowych aktach. Należą do nich przede wszystkim:

- dyrektywa w sprawie kwalifikowania (2011/95) z 13 grudnia 2011 r.;

- dyrektywa w sprawie procedur azylowych (2013/32) z 26 czerwca 2013 r.;

- dyrektywa w sprawie warunków przyjmowania (2013/33) z 26 czerwca 2013 r.;

- rozporządzenie w sprawie Eurodac (2013/603) z 26 czerwca 2013 r.;

- rozporządzenie Dublin II (2013/604) z 26 czerwca 2013 r.

Dyrektywa w sprawie warunków kwalifikowania z 2011 r. stawia sobie za cel określenie norm dotyczących kwalifikowania obywateli państw trzecich lub bezpaństwowców do ochrony międzynarodowej. Omawia procedury związane z oceną wniosków azylowych, kryteria umożliwiające ubieganie się o status uchodźcy lub ochronę uzupełniająca, prawa przysługujące osobom objętym ochroną (m.in. utrzymanie jedności rodziny, dostęp do edukacji, zatrudnienia, opieki zdrowotnej, socjalnej itd.) (Dyrektywa 2011/95, s. 9-26).

Dyrektywa w sprawie procedur azylowych jest jednym z pakietu aktów przyjętych 26 czerwca $2013 \mathrm{r}$. Zmierza ona do stworzenia wspólnych procedur przyznawania i cofania ochrony międzynarodowej. Dokument odwołuje się do ww. dyrektywy z 2011 r., jak również do konwencji genewskiej i protokołu nowojorskiego. Precyzuje szczegóły związane z procedura, m.in. regulując kwestie przesłuchania wnioskodawcy, pomocy prawnej, dopuszczalności wniosków, wycofania wniosku, postępowania odwoławczego, bezpiecznego kraju pochodzenia bądź bezpiecznego kraju trzeciego (Dyrektywa 2013/32, s. 60-95). 
Dyrektywa w sprawie warunków przyjmowania określa warunki pobytu wnioskodawców w danym państwie unijnym w oczekiwaniu na rozpatrzenie wniosku o ochronę międzynarodową. Dokument przewiduje odpowiednie standardy z zakresu wyżywienia, zakwaterowania, dostępu do opieki zdrowotnej, zatrudnienia, świadczeń materialnych itp. Dyrektywa - co do zasady - przyznaje wnioskodawcom prawo do swobodnego przemieszczania się $\mathrm{w}$ danym państwie lub na wyznaczonym przez władze państwowe obszarze (art. 7). Jednocześnie dopuszcza możliwość zatrzymania wnioskodawcy, wyliczając sytuacje, w których można taki środek zastosować (art. 8-11) (Dyrektywa 2013/33, s. 96-116).

Rozporządzenie w sprawie Eurodac odnosi się do unijnej bazy danych zawierającej odciski palców osób wnioskujących o azyl. Rozporządzenie umożliwiło ponadto korzystanie z niej Europolowi i policjom państw członkowskich. Warto podkreślić, że Eurodac jest istotnym narzędziem ułatwiającym identyfikację osób przybywających z odległych zakątków Afryki i Azji, często nieposiadających dokumentów tożsamości. Precyzuje zasady związane z pobieraniem odcisków palców, przechowywaniem, porównywaniem i dostępem do danych i ich bezpieczeństwem itd. (Rozporządzenie 603/2013, s. 1-30).

Zasadniczym celem ostatniego $\mathrm{z}$ wymienionych dokumentów, tj. rozporządzenia Dublin II, jest wprowadzenie mechanizmów i kryteriów pozwalających na ustalenie państwa, na którym spoczywa obowiązek rozpatrzenia wniosku o ochronę międzynarodową. Artykuły 7-15 hierarchizują wspomniane kryteria, poczynając od obecności $\mathrm{w}$ danym państwie członków rodziny wnioskodawcy, poprzez posiadanie ważnego dokumentu pobytu bądź wizy danego państwa. Nie wnikając w szczegóły przepisów rozporządzenia, według dalszych kryteriów odpowiedzialność za rozpatrzenie wniosku ponosi pierwsze państwo, na którego terytorium znalazł się wnioskodawca (w praktyce jest to najczęstsza sytuacja w obliczu kryzysu migracyjnego), czy wreszcie państwo, na którego obszarze przebywa wnioskodawca w strefie tranzytu międzynarodowego lotniska. Dokument opisuje też kwestie związane z przejęciem odpowiedzialności za rozpatrzenie wniosku przez inne państwo członkowskie UE i inne znaczące zagadnienia (Rozporządzenie 604/2013, s. 31-59).

Powyższe akty prawne są zatem podstawą dla procedur związanych z przyjmowaniem osób ubiegających się o pomoc ze strony UE. W praktyce zaczynają się one od pobrania odcisków palców od osoby wnioskującej o azyl, przyznania zakwaterowania i wyżywienia. Kolejnym krokiem jest przesłuchanie wnioskodawcy w celu uprawdopodobnienia, czy rzeczywiście istnieją przesłanki do udzielenia mu ochrony międzynarodowej. W przypadku negatywnej decyzji wnioskodawca ma prawo do odwołania. Przyznanie azylu bądź ochrony uzupełniającej powoduje uzyskanie przez daną osobę określonych praw związanych z pobytem, zatrudnieniem czy ochroną zdrowia.

\section{Decyzje UE w następstwie kryzysu migracyjnego}

Narastający nacisk migracyjny ze strony afrykańskich i bliskowschodnich uciekinierów zaczął wywierać coraz silniejszą presję na kręgi polityczne UE. Latem $2015 \mathrm{r}$. minister spraw wewnętrznych RFN Thomas de Maizière zapowiedział przybycie do Niemiec ok. 800 tys. imigrantów, korygując tym samym znacznie niższe (450 tys.) 
wcześniejsze przewidywania (Im Auge, 2013). 25 sierpnia 2015 r. nastapiło ogłoszenie przez Federalny Urząd ds. Migracji i Uchodźców brzemiennej w skutkach decyzji, iż Niemcy w stosunku do uciekinierów z Syrii odchodzą od regulacji dublińskich, sprowadzających się do obowiązku rozpatrzenia wniosku azylowego przez pierwsze unijne państwo pobytu imigranta (Syrien-Flüchtlinge dürfen, 2015). Rozstrzygnięciu temu towarzyszyło porozumienie pomiędzy kanclerzami Niemiec i Austrii, Angelą Merkel i Wernerem Faymannem, które z jednej strony motywowane było pobudkami humanitarnymi, z drugiej zaś zmierzało do rozładowania ogromnej fali imigrantów maszerującej z Węgier w stronę Austrii. Dnia 31 sierpnia 2015 r., Angela Merkel na konferencji prasowej wypowiedziała słynne, powtarzane wielokrotnie później słowa: Wir schaffen das! (możemy to zrobić, damy radę). O ile pani kanclerz, otwierając granice Niemiec, zaskarbiła sobie serca imigrantów szukających tam schronienia, to u wielu własnych obywateli ta kontrowersyjna decyzja, naruszająca reguły systemu dublińskiego, wzbudziła odruch protestu. Wkrótce zresztą władze federalne zaczęły stopniowo odwracać jej skutki. 13 września 2015 r. minister de Maizière zapowiedział przywrócenie przez Niemcy kontroli granicznych (Im Auge, 2015). Miesiąc później, 15 października 2015 r. w Bundestagu uchwalono ustawę o przyspieszeniu procedur azylowych (Asylverfahrenbeschleunigungsgesetz, 2015). Nie wnikając w ocenę słuszności sierpniowej decyzji władz niemieckich należy skonstatować, że przyniosła spory ładunek kontrowersji zarówno na niemieckiej, jak i europejskiej scenie politycznej, stając się katalizatorem debaty na temat kryzysu imigracyjnego (szerzej zob. Koszel, 2016, s. 143-156).

Fala imigracji z 2015 r., która skłoniła Angelę Merkel do odstapienia od przepisów europejskiego prawa azylowego i czasowego otwarcia granic Niemiec dla imigrantów, stała się także katalizatorem decyzji unijnych, zmierzających do rozładowania problemu i odciążenia państw najbardziej obarczonych napływem cudzoziemców. W 2015 r. kwestia ta była przedmiotem działań szeregu instytucji europejskich, poczynając od propozycji Komisji Europejskiej, poprzez konkluzje Rady Europejskiej aż po konkretne akty prawne Parlamentu Europejskiego i Rady. Na potrzeby niniejszego opracowania skoncentrujemy się na najistotniejszych aktach instytucji UE, które nałożyły na państwa członkowskie określone zobowiązania, a tym samym zrodziły ożywioną debatę niosącą bagaż ogromnych kontrowersji.

Dnia 20 lipca 2015 r. Rada ds. Wymiaru Sprawiedliwości i Spraw Wewnętrznych przyjęła dwa istotne dokumenty. Pierwszy z nich obejmował konkluzje w sprawie przesiedlenia 20 tys. osób. Odwoływał się do wcześniejszych dokumentów (oświadczenia Rady Europejskiej z 23 kwietnia 2015 r., konkluzji Rady Europejskiej z 26 czerwca 2015 r., konkluzji Rady z 10 października 2014 r. i komunikatu Komisji Europejskiej dotyczącego programu migracji z 13 maja 2015 r.). W konkluzjach wyrażono zgodę na podział 20 tys. osób wymagających ochrony międzynarodowej pomiędzy państwa członkowskie UE oraz cztery państwa spoza Unii, które wyraziły zgodę na udział w tym przedsięwzięciu (Norwegia, Islandia, Liechtenstein i Szwajcaria). W istocie - jak wynikało z załącznika - liczba ta wynosiła 22504 osoby, przy czym 18415 osób zostało rozdysponowanych pomiędzy 27 państw UE (bez Węgier), zaś pozostałe 4089 osób miało zostać przesiedlonych do wymienionych czterech państw spoza UE. Polska zadeklarowała przyjęcie 900 osób (Konkluzje przedstawicieli rządów, 2015). 
Na tym samym posiedzeniu (20 lipca 2015 r.) Rada przyjęła ponadto rezolucję dotyczącą relokacji z Włoch i Grecji. Także w tym wypadku odwołano się do wspomnianych wyżej dokumentów Rady Europejskiej z kwietnia i czerwca 2015 r. W rezolucji postanowiono dokonać relokacji 40 tys. z obu wymienionych państw w ciagu dwóch lat, przy czym w pierwszej kolejności relokacja obejmowałaby 32256 osób (w załączniku do rezolucji dokonano ich podziału na poszczególne państwa), zaś do końca roku 2015 r. przewidywano rozdysponowanie pozostałych 7744 osób. Wspomnianą liczbę 32256 imigrantów podzielono pomiędzy 24 państwa członkowskie UE (bez Austrii i Węgier oraz Danii i Wielkiej Brytanii). Polska zadeklarowała przyjęcie 1100 osób. Pojawiła się też skierowana do państw UE sugestia uznania państw bałkańskich za bezpieczne kraje pochodzenia (Rezolucja przedstawicieli, 2015; całość wniosków z posiedzenia Rady z 20 lipca 2015 r. zob. Outcome, 2015). Należy jednocześnie podkreślić, że pierwszy dokument mówił o przesiedleniach, natomiast drugi o relokacji. Wypada zatem wyjaśnić, iż pierwszy termin dotyczy transferu osób przebywających w obozach poza Unią do jej państw członkowskich, drugi z kolei oznacza przemieszczanie osób z jednego do innych państw członkowskich.

Powyższa rezolucja stała się punktem wyjścia dla decyzji (decyzji w sensie aktu prawa pochodnego) Rady dotyczącej relokacji w okresie dwóch lat 40 tys. osób z Włoch i Grecji, która została uchwalona 14 września 2015 r. Jako podstawę traktatową przywołano art. 78 ust. 3 TFUE, który przewiduje, że ,gdy jedno lub więcej Państw Członkowskich znajdzie się w nadzwyczajnej sytuacji charakteryzującej się nagłym napływem obywateli państw trzecich, Rada, na wniosek Komisji, może przyjąć środki tymczasowe na korzyść zainteresowanego Państwa lub Państw Członkowskich. Rada stanowi po konsultacji z Parlamentem Europejskim" (TFUE, art. 78 ust. 3). Warto zwrócić uwagę na powyższe zapisy, ponieważ późniejsze skargi Węgier i Słowacji na wrześniowe decyzje Rady (o czym w dalszej części) odwoływały się m.in. do przytoczonego artykułu TFUE. Oznaczało to odejście od dotychczasowych zasad związanych z ustalaniem państwa odpowiedzialnego za rozpatrzenie wniosku o ochronę (zgodnych z rozporządzeniem 604/2013, o którym była mowa wcześniej), które w praktyce dotąd obciążały Grecję i Włochy. Zgodnie z art. 4 decyzji, 24 tys. osób miało podlegać relokacji z Włoch, zaś 16 tys. z Grecji. Irlandia, Wielka Brytania i Dania zostały wyłączone ze stosowania decyzji w oparciu o stosowne protokoły dołączone do TFUE, dopuszczające możliwość wyłączenia tych państw z obowiązku przyjmowania aktów w ramach Przestrzeni Wolności, Bezpieczeństwa i Sprawiedliwości (Protokót nr 21; Protokót nr 22; oba protokoły przewidują możliwość nieuczestniczenia wspomnianych państw w PWBiS, tj. w przyjmowaniu środków objętych tytułem V części trzeciej TFUE). Każde państwo powinno powołać punkt kontaktowy do współdziałania z Europejskim Urzędem Wsparcia w Dziedzinie Azylu (European Asylum Support Office - EASO). Decyzja umożliwiła również delegowanie oficerów łącznikowych oraz ekspertów do Grecji i Włoch, m.in. do działań wspierających identyfikację wnioskodawców i innych form wsparcia. Przewidziano możliwość tymczasowego zawieszenia udziału danego państwa w relokacji (przez Radę, na wniosek KE i po konsultacji z PE) w przypadku nagłego napływu imigrantów w oparciu o przytaczany wyżej art. 78 TFUE (art. 9 decyzji). Za każdą osobę podlegającą relokacji państwo członkowskie otrzymałoby kwotę 6 tys. euro. Termin realizacji decyzji 
wyznaczono na dzień 17 września 2017 r. (art. 13). Warto zwrócić szczególną uwagę na jeszcze jeden zapis, zawarty w punkcie 28 preambuły decyzji. Stwierdzono w nim, że w procedurze kwalifikowania wnioskodawców do relokacji w poszczególnych państwach „,szczególną uwagę należy poświęcić szczególnym umiejętnościom i cechom danych wnioskodawców, takim jak znajomość języków i inne indywidualne elementy oparte na udowodnionych więzach rodzinnych, kulturowych lub społecznych, co mogłoby ułatwić ich integrację w społeczeństwie państwa członkowskiego relokacji. [...] Z należytym poszanowaniem zasady niedyskryminacji państwa członkowskie relokacji mogą wskazać swoje preferencje dotyczące wnioskodawców [...]" (Decyzja 2015/1523, 2015, s. 146-156). Wydaje się zatem, że powyższy zapis daje (a przynajmniej powinien) państwom członkowskim wpływ na dobór imigrantów przeznaczonych do relokacji.

Kilka dni później, 22 września 2015 r., Rada uchwaliła kolejną decyzję. Powtórzyła ona znaczną część zapisów z decyzji 2015/1523 (w tym wyżej omówione). W dokumencie postanowiono relokować 120 tys. osób do państw Unii według następujących założeń: 15600 osób z Włoch, 50400 z Grecji, natomiast pozostałe 54 tys. osób miały zostać później rozlokowane z obu państw proporcjonalnie do danych znajdujących się w załącznikach, precyzujących liczby wnioskodawców przypadające na poszczególne państwa członkowskie. Państwa mogły ubiegać się o czasowe zawieszenie relokacji do 30\% wnioskodawców, przy czym decyzję w tej sprawie mogła podjać Rada w oparciu o opinię KE (art. 4). Termin realizacji decyzji wyznaczono na 26 września 2017 r. Na Polskę przypadła liczba 5082 osób (1201 z Włoch i 3881 z Grecji) (Decyzja 2015/1601, 2015, s. 80-94).

\section{Porozumienie z Turcją i dalsze kroki UE}

Gwałtowny napływ imigrantów syryjskich, przedostających się drogą morską z Turcji do Grecji, postawił na porządku dziennym problem uszczelnienia zewnętrznej granicy UE na tamtejszym szlaku. Potrzebą chwili stało się wypracowanie odpowiedniego porozumienia z Turcją, w celu aktywnego włączenia Ankary do działań zmierzających do powstrzymania napływu imigrantów. Sytuację dodatkowo komplikowały pogarszające się relacje pomiędzy coraz wyraźniej zmierzającą w kierunku autorytaryzmu Turcją a piętnująca te procesy Unia, zwłaszcza Niemcami. Pragmatyzm wymagał jednak ograniczenia krytycznych uwag wobec dyktatorskich zapędów prezydenta Recepa Tayyipa Erdoğana.

Historia traktatowych relacji pomiędzy Wspólnotami Europejskimi a tym stojącym w rozkroku pomiędzy Europą a Azją państwem sięgała 1963 roku, gdy zawarta została umowa o stowarzyszeniu Turcji ze Wspólnotami. Negocjacje akcesyjne, które toczyły się od 2005 r., obciążone były od początku niechętnym stanowiskiem części państw członkowskich Unii. Co ważne, w gronie przeciwników tureckiej akcesji były m.in. Francja czy niemieccy chadecy, oferujący raczej uprzywilejowane partnerstwo niż pełne członkostwo. Zastrzeżenia związane $\mathrm{z}$ odmiennością kulturową, jak i deficytem demokracji umacniającego autorytarne rządy prezydenta Erdoğana skutecznie zniechęcały do przyspieszenia procesu akcesyjnego. 
Problem imigracyjny, jak zaznaczono, wymusił w 2015 r. mniej pryncypialne a bardziej pragmatyczne podejście do relacji z Turcją i stłumienie krytyki z powodu naruszania praw człowieka $\mathrm{w}$ tym państwie. Podstawą traktatową w kwestii migracji była zawarta 16 grudnia 2013 r. dwustronna umowa o readmisji. Układ zawarto na czas nieokreślony z półrocznym terminem wypowiedzenia. Zgodnie z art. 24 ust. 3 porozumienia, przepisy dotyczące readmisji obywateli państw trzecich miały zacząć obowiązywać trzy lata po wejściu w życie umowy (Umowa między Uniq Europejska a Republika Turcji, 2014, s. 3-27). Nastapiło to 1 października 2014 r. (Informacja dotyczqca, 2014, s. 1), zatem wspomniana data miała upłynąć dopiero 1 października 2017 r. W obliczu kryzysu migracyjnego jednak dramatycznie zmieniły się okoliczności i wzmogła się presja państw UE, zamierzających nakłonić Turcję do przyspieszenia realizacji tej części umowy readmisyjnej. Drogę ku temu otworzyło spotkanie UE-Turcja z 29 listopada 2015 r., na którym zdecydowano o zintensyfikowaniu dialogu politycznego na szczeblach ministerstw, Wysokiego Przedstawiciela ds. Zagranicznych i Polityki Bezpieczeństwa oraz członków KE, jak również przyspieszyć rozmowy na temat liberalizacji reżimu wizowego (Szczyt przywódców UE z Turcja, 2015). Kolejne spotkania nastąpily 7 marca 2016 r. oraz 18 marca 2016 r. Efektem tego ostatniego było oświadczenie obu stron, w którym Turcja zobowiązywała się do ścisłej współpracy zmierzającej do utrudnienia Syryjczykom przedostawania się z Turcji do Grecji. Już od 20 marca imigranci zmierzający na greckie wybrzeże mieli być odsyłani do Turcji (pkt 1 oświadczenia). W zamian za każdego odesłanego Syryjczyka miało następować przesiedlenie innego Syryjczyka z Turcji do Unii. Pierwszeństwo uzyskiwali ci imigranci, którzy nie próbowali wcześniej nielegalnie przedostać się do Unii (pkt 2). Postanowiono przyspieszyć dialog na temat liberalizacji reżimu wizowego, zapowiadając zniesienie wiz dla obywateli tureckich w miarę możliwości do końca czerwca 2016 r. (pkt 5). Kolejne punkty zapowiadały dwuetapowe finansowanie działań powstrzymujących napływ imigrantów w kwocie łącznie 6 mld euro do końca 2018 r. (pkt 6) oraz przyspieszenie procesu akcesyjnego Turcji do UE (pkt 8) (Oświadczenie UE-Turcja, 2016). Brak postępów w zakresie dialogu wizowego w kolejnych miesiącach wzbudzał irytację Ankary, niemniej jednak marcowe porozumienie spowodowało wyraźny spadek liczby imigrantów przybywających z Turcji do Grecji. Zgodnie z raportem Komisji Europejskiej na temat realizacji porozumienia, średnia liczba migrantów docierających do Grecji począwszy od 1 maja 2016 r. skurczyła się z 1740 do zaledwie 47 dziennie (Komunikat Komisji Europejskiej, 2016).

Istotne modyfikacje dotychczasowych postanowień przyniosła decyzja Rady 2016/1754 z 29 września 2016 r. Dokonywała ona uzupełnień decyzji 2015/1601 z 22 września 2015 r. Przypomnijmy, że tamten dokument dotyczył relokacji 120 tys. imigrantów, przy czym w załącznikach dokonano podziału 66 tys. osób, nie rozdysponowano natomiast wówczas puli 54 tys. osób. Art. 1 decyzji z września 2016 r. uzupełniał tę lukę. Rozszerzał on zapisy decyzji 2015/1601 przewidując, że wspomniana pula 54 tys. osób może objąć imigrantów syryjskich z Turcji zamiast (jak to zakładano we wrześniu 2015 r.) z Grecji i Włoch (Decyzja 2016/1754, 2016, s. 82-84). W praktyce zatem relokacje (czyli transfer migrantów wewnątrz Unii) zastępowane były przesiedleniami (czyli transferem migrantów spoza Unii, tj. z Turcji do Unii). Decyzja wynikała z faktu, że rzeczywista liczba imigrantów przeznaczonych do relo- 
kacji z Włoch i Grecji była niższa, niż przewidywano w decyzji 2015/1601 (abstrahując od faktu, iż przybywali kolejni, zwłaszcza do Włoch). Decyzję 2016/1754 można też traktować jako konsekwencję marcowego porozumienia z Turcją, przewidującego - jak pamiętamy - transfer z Turcji do Unii uciekinierów syryjskich (jeden Syryjczyk za każdą udaremnioną próbę nielegalnego przedostania się z Turcji do UE).

\section{Stan realizacji relokacji i przyznawania ochrony międzynarodowej - maj 2017 roku}

Precyzyjny obraz dotyczący przyznawania imigrantom ochrony międzynarodowej w UE ilustrują regularne raporty Europejskiego Urzędu Wsparcia w dziedzinie Azylu. Najnowsze dane, dostępne $\mathrm{w}$ chwili pisania niniejszego artykułu, pochodziły z maja 2017 r. i podawały liczbę 59128 złożonych wniosków azylowych, co oznaczało 18-procentowy wzrost $\mathrm{w}$ porównaniu z poprzednim miesiącem i jednocześnie 40-procentowy spadek w stosunku do maja 2016 r. Podobnie jak we wcześniejszych miesiącach, największa liczba aplikantów pochodziła z Syrii (8510), Afganistanu (3955), Iraku (3826) i Nigerii (3589). Jednocześnie najwięcej wniosków rozpatrzonych w tym samym miesiącu dotyczyło obywateli Afganistanu (ponad 24 tys.), następnie Syrii (ponad 14 tys.), Iraku (ponad 12 tys.) i Nigerii (ponad 6,6 tys.). Interesująco przedstawiał się rozkład pozytywnych decyzji (łącznie 37\% wszystkich wniosków), tzn. przyznających ochronę międzynarodową, czyli status uchodźcy bądź ochronę uzupełniającą (nie wnikając w szczegóły, ten drugi status dotyczy osób nie kwalifikujących się do statusu uchodźcy, lecz posiadających uzasadnioną obawę przed prześladowaniami). Ochronę międzynarodową otrzymało aż 97\% wnioskodawców z Syrii i 89\% z Erytrei, nieco ponad połowa imigrantów z Iraku i Iranu, natomiast w przypadku Afganistanu odsetek ten wyniósł 29\% (Latest, 2017). Świadczyło to dobitnie o skłonności państw UE do przyznawania azylu lub ochrony uzupełniającej osobom najbardziej narażonym na prześladowania: uciekającym przed wojną Syryjczykom i żyjącym w warunkach brutalnej dyktatury Erytrejczykom.

Z kolei dane dotyczące relokacji imigrantów na podstawie decyzji z września 2015 r., opublikowane w raporcie Komisji Europejskiej z 16 maja 2017 r. wskazywały, że dokonano jej zaledwie wobec 18418 osób (stan na 12 maja 2017 r.). Niemal 4,5 tys. zostało skierowanych do Niemiec, na drugim miejscu lokowała się Francja, która przyjęła ponad 3,4 tys. osób (Relocation, 2017). Dokładne dane przytacza poniższa tabela.

\begin{tabular}{||l|c|c|c||}
\hline \multicolumn{1}{|c|}{ Państwo relokacji } & $\begin{array}{c}\text { Liczba relokowanych } \\
\mathbf{z} \text { Włoch }\end{array}$ & $\begin{array}{c}\text { Liczba relokowanych } \\
\text { z Grecji }\end{array}$ & $\begin{array}{c}\text { Lączna liczba } \\
\text { relokowanych }\end{array}$ \\
\hline \multicolumn{1}{|c|}{1} & 2 & 3 & 4 \\
\hline Austria & 0 & 0 & 0 \\
\hline Belgia & 121 & 430 & 551 \\
\hline Bułgaria & 0 & 29 & 29 \\
\hline Chorwacja & 13 & 36 & 79 \\
\hline Cypr & 18 & 55 & 12 \\
\hline Czechy & 0 & 12 & \\
\hline
\end{tabular}




\begin{tabular}{|c|c|c|c|}
\hline 1 & 2 & 3 & 4 \\
\hline Dania & 0 & 0 & 0 \\
\hline Estonia & 0 & 122 & 122 \\
\hline Finlandia & 653 & 790 & 1443 \\
\hline Francja & 330 & 3074 & 3404 \\
\hline Hiszpania & 144 & 742 & 886 \\
\hline Holandia & 565 & 1211 & 1776 \\
\hline Niemcy & 2048 & 2430 & 4478 \\
\hline Irlandia & 0 & 459 & 459 \\
\hline Litwa & 8 & 267 & 275 \\
\hline Luksemburg & 61 & 216 & 277 \\
\hline Łotwa & 27 & 281 & 308 \\
\hline Malta & 47 & 79 & 126 \\
\hline Polska & 0 & 0 & 0 \\
\hline Portugalia & 299 & 1003 & 1302 \\
\hline Rumunia & 45 & 523 & 568 \\
\hline Słowacja & 0 & 16 & 16 \\
\hline Słowenia & 35 & 137 & 172 \\
\hline Szwecja & 39 & 0 & 39 \\
\hline Węgry & 0 & 0 & 0 \\
\hline UE lącznie & 4453 & 11912 & 16353 \\
\hline Liechtenstein & 0 & 10 & 10 \\
\hline Norwegia & 679 & 468 & 1147 \\
\hline Szwajcaria & 579 & 317 & 896 \\
\hline Lącznie & 5711 & 12707 & 18418 \\
\hline
\end{tabular}

Obliczenia na podstawie: Relocation and Resettlement - State of Play, 16 May 2017, European Commission, https:/ec.europa.eu/home-affairs/sites/homeaffairs/files/what-we-do/policies/european-agendamigration/20170516_update_of_the_factsheet_on_relocation_and_resettlement_en.pdf.

Lektura tabeli w zestawieniu z zobowiązaniami zaciągniętymi we wrześniu $2015 \mathrm{r}$. wskazuje, że część państw w niewielkim stopniu lub w ogóle nie rozpoczęła ich realizacji. Krytyczne uwagi z powodu powolnego tempa relokacji znalazły się w rezolucji Parlamentu Europejskiego z 18 maja 2017 r. (aczkolwiek opierała się ona na nieco wcześniejszym raporcie KE, który podawał liczbę 17903 relokowanych osób na dzień 27 kwietnia 2017 r.). Skonstatowano w niej, że faktyczna liczba osób przebywających w Grecji i Włoszech i zakwalifikowanych do relokacji jest mniejsza od liczby przewidzianej w decyzjach Rady z września 2015 r., jednak do obu państw wciąż docierają kolejni przybysze. W dokumencie odnotowano, że tylko Malta i Finlandia „są na najlepszej drodze do wywiązania się z obowiązków w zakresie relokacji, [...] dwa państwa członkowskie w ogóle nie uczestniczą w relokacji" (Rezolucja Parlamentu Europejskiego, 2017). W tym ostatnim wypadku chodziło o Polskę i Węgry.

Kontrowersje dotyczące postanowień o relokacji z czasem zaczęły przybierać bardzo burzliwą formę. Dość zauważyć, że odmowa ich realizacji przez Polskę i Wegry zbiegła się z zarzutami Komisji Europejskiej i części członków UE wobec obu państw, dotyczącymi naruszania wartości, na których opiera się UE, wskazanych w art. 2 Traktatu o Unii Europejskiej (TUE). Szczególnie niejednoznaczne oceny odnosiły się do decyzji 2015/1601 o rozlokowaniu 120 tys. imigrantów, która została przegłosowana przy sprzeciwie Czech, Słowacji, Węgier, Rumunii oraz wstrzymującym się głosie 
Finlandii. Węgry i Słowacja zdecydowały już w grudniu 2015 r. o złożeniu skarg do Trybunału Sprawiedliwości Unii Europejskiej (TSUE) o stwierdzenie nieważności decyzji 2015/1601. Słowacja podniosła sześć zarzutów wobec powyższego aktu. Nie wnikając głęboko w detale prawne, można zrekapitulować, że najważniejsze z nich dotyczyły:

- naruszenia zapisów traktatowych powierzających Radzie Europejskiej określanie strategicznych wytycznych z zakresu Przestrzeni Wolności, Bezpieczeństwa i Sprawiedliwości (art. 68 TFUE);

- naruszenia zapisów przewidujących, iż instytucje UE działają w granicach uprawnień przyznanych im Traktatami (art. 13 ust. 2 TUE), zgodnie z zasadami równowagi instytucjonalnej, demokracji przedstawicielskiej i dobrej administracji;

- zakwestionowania art. 78 ust. 3 TFUE, stanowiącego w opinii Słowacji niewłaściwą podstawę przyjęcia decyzji o relokacji (jako przewidującego niewłaściwą procedurę dla tego rodzaju decyzji, jak również niespełnienia warunków jego zastosowania, tzn. tymczasowego charakteru przyjętych środków i zaistnienia pilnej sytuacji w następstwie nagłego napływu cudzoziemców);

- naruszenia zasady jawności w trakcie negocjacji i głosowania w Radzie i innych wymogów proceduralnych, takich jak brak regularnych konsultacji z Parlamentem Europejskim (wymóg konsultacji z PE zawiera art. 78 ust. 3 TFUE) czy brak jednogłośnego stanowiska Rady odnośnie zmian wprowadzonych do pierwotnego projektu Komisji Europejskiej (art. 293 TFUE);

- naruszenia zasady proporcjonalności (przewiduje ona, zgodnie z art. 5 ust. 4 TUE, że zakres i forma działania UE nie wykraczają poza to, co jest konieczne dla osiągnięcia traktatowych celów Unii) (Skarga wniesiona... Sprawa C-643/15, 2016, s. 41-43).

Znaczna część zarzutów słowackich została powtórzona w skardze Węgier. Budapeszt domagał się stwierdzenia nieważności decyzji 2015/1601, zaś w przypadku jej podtrzymania przez TSUE, stwierdzenia jej nieważności w odniesieniu do Węgier. Dodatkowo podniósł m.in. zarzut sprzeczności decyzji 2015/1601 z konwencją genewską dotyczącą statusu uchodźców w tym sensie, że w praktyce decyzja nie dawała imigrantom prawa wyboru państwa, w którym zamierzaliby złożyć wniosek azylowy (pkt 8 skargi). Pojawił się ponadto argument o znacznej liczbie nielegalnych imigrantów, którzy dotarli do terytorium Węgier (pkt 10 skargi) (Skarga wniesiona... Sprawa C-647/15, 2016, s. 43-44).

Sprawa przed TSUE w oparciu o skargi obu państw, które poparła także Polska, odbyła się 10 maja 2017 r. Strony przedstawiły swoje argumenty, zaś ostateczny werdykt - jak przewidywano - miał zostać wydany w ciagu najbliższych miesięcy (Trybunat w Luksemburgu, 2017). Nastąpiło to 6 września 2017 r. - skargi zostały oddalone (Wyrok Trybunatu, 2017).

Problem imigracyjny daleki jest od rozwiązania. O ile napływ imigrantów z terytorium Turcji udało się w wyniku porozumienia z marca 2016 r. zmniejszyć, to nadal ogromne ich rzesze przybywają do Włoch z Afryki, przede wszystkim z pograżonej w chaosie Libii. Przez pierwszą połowę 2017 r. do Włoch dotarło niemal 84 tys. osób (Hlebowicz, 2017a). W tej sytuacji najpilniejszą potrzebą stało się ograniczenie imigracji na szlaku śródziemnomorskim. W lutym 2017 r. przewodniczący Parlamentu 
Europejskiego, Antonio Tajani, opowiedział się m.in. za utworzeniem odpowiednio wyposażonych ośrodków recepcyjnych dla uchodźców w Libii oraz zaproponował cały szereg działań, ujętych w robocze hasło planu Marshalla dla Afryki (Antonio Tajani, 2017). Z kolei 11 maja 2017 r. ministrowie spraw wewnętrznych Włoch i Niemiec, Marco Minniti i Thomas de Maizière, zaproponowali utworzenie unijnej misji strzegącej południowej granicy Libii (Bewarder, Schilz, 2017). Z kolei na spotkaniu ministrów spraw wewnętrznych UE w Tallinie z początkiem lipca $2017 \mathrm{r}$. omawiali oni m.in. takie kwestie, jak utworzenie w Libii specjalnego ośrodka zajmującego się ratowaniem migrantów z Morza Śródziemnego, wprowadzenie pewnych ułatwień wizowych dla państw afrykańskich współpracujących z Unią w działaniach zmierzających do ograniczenia nielegalnej imigracji czy większe wsparcie finansowe libijskiej straży granicznej (Hlebowicz, 2017b).

\section{Wnioski}

W publicznej debacie na temat kryzysu migracyjnego ścierają się różne racje. $Z$ jednej strony Europa staje w obliczu moralnego obowiązku pomocy ludziom uciekającym przed wojną i przemocą (zwłaszcza z Syrii czy Erytrei), ale i skrajną biedą, ryzykującym często życie, zdrowie lub wolność w drodze do Starego Kontynentu. O tragicznej sytuacji afrykańskich migrantów, padających ofiarami gwałtów i innych form przemocy, informowały raporty UNICEF (A Deadly, 2017). Z drugiej strony wraz z kolejnymi zamachami terrorystycznymi przeprowadzanymi przez fundamentalistów islamskich, mieszkańcy Europy odczuwają coraz większy niepokój o swoje bezpieczeństwo. Obawiają się również niekorzystnych zmian demograficznych wskutek napływu imigrantów, a w konsekwencji narastania postaw roszczeniowych na rzecz respektowania pewnych zachowań kulturowych, które są nie do pogodzenia z systemem wartości europejskiego Zachodu. Potrzebne jest zatem znalezienie złotego środka pomiędzy uszanowaniem tych lęków a potrzebą wsparcia osób, które rzeczywiście potrzebują pomocy. Należy wyraźnie skonstatować, że Europa nie jest w stanie wchłonąć dowolnej liczby imigrantów potrzebujących pomocy. Proponowana przez niektóre państwa, choć obecnie chyba nieciesząca się już wielką popularnością koncepcja stałego rozdzielnika imigrantów na poszczególne państwa, wydaje się być chybionym pomysłem, choćby ze względu na możliwość umocnienia nastrojów ksenofobicznych podszytych zarzutami o ograniczanie suwerenności państw członkowskich i poczuciem „,narzucania” określonych rozwiązań przez UE. Z drugiej strony przyjęcie choćby niewielkiej, wręcz symbolicznej grupy imigrantów potrzebujących pomocy przez państwa uchylające się od tego zobowiązania stanowiłoby znaczący gest w kontekście solidarności europejskiej. Na dłuższą metę należałoby zalecić wzmacnianie kontroli granic zewnętrznych UE. W tym kontekście ważna rola będzie przypadać Europejskiej Straży Granicznej i Przybrzeżnej, która powinna zostać wyposażona w efektywne narzędzia umożliwiające monitorowanie sytuacji na zewnętrznych granicach Unii. Ponadto konieczna jest współpraca UE z państwami jej sąsiedztwa (wschodnia i południowa granica Unii). W tych okolicznościach wzrośnie skłonność do „przymykania oka" na deficyty demokracji np. w państwach Afryki Północnej (jak np. w przypadku 
porozumienia z Turcją), w których mogłyby ewentualnie powstawać obozy detencyjne. Następstwa obalenia Muammara Kaddafiego w 2011 r., jakkolwiek kroku uzasadnionego z etycznego punktu widzenia, stały się przestrogą, wyraźnie ilustrującą scenariusz chaosu w przypadku braku silnego przywództwa i przeistaczania się w państwo upadłe. Obozy detencyjne natomiast wymagałyby odpowiedniego nadzoru ze strony UNHCR i państw UE w celu zagwarantowania humanitarnych warunków pobytu osób oczekujących na rozpatrzenie wniosków azylowych. Nade wszystko należy również umacniać instrumenty z zakresu Wspólnej Polityki Bezpieczeństwa i Obrony w celu stabilizowania najbliższego sąsiedztwa Unii.

\section{Bibliografia}

A Deadly Journey for Children. The Central Mediterrean Migration Route, UNICEF - Child Alert, February 2017, https://www.unicef.org/media/files/UN053732.pdf.

Antonio Tajani: „Auffanglager dürfen keine KZs werden” (2017), „Berliner Morgenpost”, 27.02.

Asylverfahrensbeschleunigungsgesetz (2015), „Bundesgesetzblatt” I, 40, 23.10.2015.

Bewarder M., Schiltz Ch. B. (2017), De Maizière fordert EU-Grenzschutzmission in Libyen, „Die Welt", 14.05.

Decyzja Rady (UE) 2015/1523 z dnia 14 września 2015 r. ustanawiająa środki tymczasowe w obszarze ochrony międzynarodowej na rzecz Włoch i Grecji, Dziennik Urzędowy Unii Europejskiej z 15.09.2015, L 239.

Decyzja Rady (UE) 2015/1601 z dnia 22 września 2015 r. ustanawiajqca środki tymczasowe w obszarze ochrony międzynarodowej na rzecz Włoch i Grecji, Dziennik Urzędowy Unii Europejskiej z 24 września 2015 r., L 248.

Decyzja Rady (UE) 2016/1754 z dnia 29 września 2016 r. zmieniajqca decyzję (UE) 2015/1601 ustanawiajaca środki tymczasowe w obszarze ochrony międzynarodowej na rzecz Włoch i Grecji, Dziennik Urzędowy Unii Europejskiej z 1.10.2016, L 268.

Dyrektywa Parlamentu Europejskiego i Rady 2011/95/UE z dnia 13 grudnia 2011 r. w sprawie norm dotyczacych kwalifikowania obywateli państw trzecich lub bezpaństwowców jako beneficjentów ochrony międzynarodowej, jednolitego statusu uchodźców lub osób kwalifikujących się do otrzymania ochrony uzupetniajacej oraz zakresu udzielanej ochrony, Dziennik Urzędowy Unii Europejskiej z 20.12.2011, L 337.

Dyrektywa Parlamentu Europejskiego i Rady 2013/32/UE z dnia 26 czerwca 2013 r. $w$ sprawie wspólnych procedur udzielania i cofania ochrony międzynarodowej, Dziennik Urzędowy Unii Europejskiej z 29.06.2013, L 180.

Dyrektywa Parlamentu Europejskiego i Rady 2013/33/UE z dnia 26 czerwca 2013 r. w sprawie norm dotyczacych przyjmowania wnioskodawców ubiegajacych się o ochronę międzynarodowa, Dziennik Urzędowy Unii Europejskiej z 29.06.2013, L 180.

Global Trends. Forced Displacement in 2016, UNHCR, http://www.unhcr.org/5943e8a34.

Hlebowicz B. (2017a), Kilkuset migrantów dziennie. Rzym woła o pomoc, „Gazeta Wyborcza”, 4.07 .

Hlebowicz B. (2017b), Niewielka pomoc przyjaciót. UE wesprze Włochów w kryzysie migracyjnym, Rzym jednak liczyt na więcej, „Gazeta Wyborcza”, 7.07.

Im Auge des Orkans (2015), „Zeit online” 20.09.

Informacja dotyczaca wejścia w życie Umowy między Uniq Europejskq a Republika Turcji o readmisji osób przebywajacych nielegalnie, Dziennik Urzędowy Unii Europejskiej z 6.09.2014, L 267. 
Komunikat Komisji Europejskiej do Parlamentu Europejskiego, Rady Europejskiej i Rady: Drugie sprawozdanie z postępów w zakresie realizacji postanowień oświadczenia UE-Turcja, Bruksela, 15.06.2016, $\operatorname{COM}(2016) 349$ final.

Konkluzje przedstawicieli rządów państw członkowskich zebranych w Radzie w sprawie przesiedlenia - za pomocq wielostronnych i krajowych systemów - 20000 osób w sposób oczywisty wymagajacych ochrony międzynarodowej, Rada Unii Europejskiej, Bruksela, 22 lipca 2015 r., 11130/15, http://data.consilium.europa.eu/doc/document/ST-11130-2015-INIT/p1/pdf.

Konwencja dotyczqca statusu uchodźców, sporzadzona w Genewie dnia 28 lipca 1951 r., Dz. U. $\mathrm{Nr} 119$ z 20.12.1991.

Konwencja o ochronie praw człowieka i podstawowych wolności, Dz. U. Nr 61 z 10.07.1993.

Koszel B. (2016), Unia Europejska, Niemcy i problem uchodźców (2014-2016), „Rocznik Integracji Europejskiej", nr 10.

Latest asylum trends - May 2017, European Asylum Support Office, https://www.easo.europa.eu/ sites/default/files/Latest-Asylum-Trends-May-2017.pdf.

Oświadczenie UE-Turcja (18 marca 2016), http:/www.consilium.europa.eu/pl/press/press-releases/2016/03/18-eu-turkey-statement.

Outcome of the Council meeting, 3405th Council meeting, Justice and Home Affaires, Brussels, 20 July 2015, http://www.consilium.europa.eu/media/22985/st11097en15.pdf.

Protokót (nr 21) w sprawie stanowiska Zjednoczonego Królestwa i Irlandii w odniesieniu do Przestrzeni Wolności, Bezpieczeństwa i Sprawiedliwości, Traktat o Funkcjonowaniu Unii Europejskiej.

Protokót (nr 22) w sprawie stanowiska Danii, Traktat o Funkcjonowaniu Unii Europejskiej.

Protokót czwarty do Konwencji o ochronie praw człowieka i podstawowych wolności gwarantujacy niektóre prawa i wolności, inne niż już zawarte w Konwencji i Protokole nr 1 do Konwencji do Konwencji, Dz. U. Nr 36 z 4.04.1995.

Protokót dotyczqcy statusu uchodźców sporzq̨dzony w Nowym Jorku dnia 31 stycznia 1967 r., Dz. U. z 20.12.1991.

Protokót $n r 7$ do Konwencji o ochronie praw człowieka i podstawowych wolności, Dz. U. Nr 42 $\mathrm{z} 2003 \mathrm{r}$.

Relocation and Resettlement - State of Play, 16 May 2017, European Commission, https://ec.europa.eu/home-affairs/sites/homeaffairs/files/what-we-do/policies/european-agendamigration/20170516_update_of_the_factsheet_on_relocation_and_resettlement_en.pdf.

Rezolucja Parlamentu Europejskiego z dnia 18 maja 2017 r. w sprawie urzeczywistnienia relokacji, http://www.europarl.europa.eu/sides/getDoc.do?pubRef=-//EP//TEXT+TA+P8-TA-2017$0230+0+\mathrm{DOC}+\mathrm{XML}+\mathrm{V} 0 / / \mathrm{PL}$.

Rezolucja przedstawicieli rządów państw członkowskich zebranych w Radzie $w$ sprawie relokacji z Grecji i Włoch 40000 osób w sposób oczywisty wymagajacych ochrony międzynarodowej, Bruksela, 22 lipca 2015, 11131/15, http://data.consilium.europa.eu/doc/document/ST-111312015-INIT/pl/pdf.

Rozporządzenie Parlamentu Europejskiego i Rady (UE) nr 603/2013 z dnia 26 czerwca 2013 r. w sprawie ustanowienia systemu Eurodac do porównywania odcisków palców w celu skutecznego stosowania rozporzadzenia (UE) nr 604/2013 w sprawie ustanowienia kryteriów i mechanizmów ustalania państwa członkowskiego odpowiedzialnego za rozpatrzenie wniosku o udzielenie ochrony międzynarodowej złożonego w jednym z państw członkowskich przez obywatela państwa trzeciego lub bezpaństwowca oraz $w$ sprawie występowania o porównanie z danymi Eurodac przez organy ścigania państw członkowskich i Europol na potrzeby ochrony porzqdku publicznego, oraz zmieniajace rozporzqdzenie (UE) nr 1077/2011 ustanawiajace Europejska Agencję ds. Zarzqdzania Operacyjnego Wielkoskalowymi Systemami Informatycznymi w Przestrzeni Wolności, Bezpieczeństwa i Sprawiedliwości, Dziennik Urzędowy Unii Europejskiej z 29.06.2013, L 180. 
Rozporządzenie Parlamentu Europejskiego i Rady (UE) nr 604/2013 z dnia 26 czerwca 2013 r. w sprawie ustanowienia kryteriów i mechanizmów ustalania państwa członkowskiego odpowiedzialnego za rozpatrzenie wniosku o udzielenie ochrony międzynarodowej złożonego $w$ jednym z państw czlonkowskich przez obywatela państwa trzeciego lub bezpaństwowca, Dziennik Urzędowy Unii Europejskiej z 29.06.2013 r., L 180.

Skarga wniesiona w dniu 2 grudnia 2015 r. - Republika Stowacja/Rada Unii Europejskiej (Sprawa C-643/15), Dziennik Urzędowy Unii Europejskiej z 1.02.2016, C 38.

Skarga wniesiona $w$ dniu 3 grudnia 2015 r. - Wegry/Rada Unii Europejskiej (Sprawa C-647/15), Dziennik Urzędowy Unii Europejskiej z 1.02.2016, C 38.

Syrien-Flüchtlinge dürfen in Deutschland bleiben, „Spiegel online” 25.08.2015.

Szczyt przywódców UE z Turcja, 29.11.2015 - Oświadczenie UE-Turcja, http://www.consilium.euro$\mathrm{pa} . \mathrm{eu} / \mathrm{pl} / \mathrm{press} / \mathrm{press}-$ releases/2015/11/29-eu-turkey-meeting-statement.

Traktat o funkcjonowaniu Unii Europejskiej.

Trybunat w Luksemburgu zająt się skarga Stowacji i Węgier ws. uchodźców, „Dziennik Gazeta Prawna" (online), 10.05.2017.

Umowa między Uniq Europejskq a Republika Turcji o readmisji osób przebywajacych nielegalnie, Dziennik Urzędowy Unii Europejskiej z 7.05.2014, L 134.

Wyrok Trybunału (wielka izba) z dnia 6 września 2017 r. (wydanie tymczasowe), http://curia.europa. eu/juris/celex.jsf?celex $=62015$ CJ0643\&lang $1=$ pl\&type $=$ TXT\&ancre $=$.

\section{Streszczenie}

Inspiracją do przygotowania powyższego artykułu stał się kryzys imigracyjny, który dotknął Unię Europejską z początkiem drugiej dekady XXI wieku, gdy do Europy zaczęły przybywać z niespotykaną wcześniej intensywnością rzesze imigrantów uciekających przed przemocą bądź ubóstwem. Dokonano w nim przeglądu najistotniejszych podstaw prawnomiędzynarodowych dotyczących uchodźców, poczynając od konwencji genewskiej z 1951 r. Szczególna uwaga została położona na główne akty z zakresu Wspólnego Europejskiego Systemu Azylowego oraz analizę istotniejszych treści kluczowych decyzji Rady UE dotyczących relokacji imigrantów z lat 2015-2016, jak również porozumienia pomiędzy UE a Turcją na temat odsyłania nielegalnych imigrantów. W dalszej części dokonano przybliżenia danych statystycznych dotyczących przyznawania ochrony międzynarodowej w UE oraz analizy treści skarg Słowacji i Węgier przeciwko decyzjom o relokacji. Artykuł podsumowują wnioski i rekomendacje odnośnie zarządzania kryzysem migracyjnym.

Słowa kluczowe: imigracja, imigranci, kryzys imigracyjny, uchodźcy, Konwencja genewska o uchodźcach, Unia Europejska, Przestrzeń Wolności, Bezpieczeństwa i Sprawiedliwości, relokacja, przesiedlenie, azyl, Wspólny Europejski System Azylowy

\section{Immigration crisis in the EU 2015-2017. Legal and political aspects}

\section{Summary}

The immigration crisis that hit the European Union at the beginning of the second decade of the 21 st century, when to Europe began to come with unprecedented intensity immigrants fleeing violence or poverty, has inspired the preparation of this article. It reviews the most important international legal bases for refugees, beginning with the Geneva Convention of 1951. 
Particular attention has been given to the main acts of the Common European Asylum System and to the analysis of the major content of the main Council decisions on the relocation of immigrants from 2015 to 2016 as well as the agreement between the EU and Turkey on the return of illegal immigrants. The following is the statistics on the granting of international protection in the EU and the analysis of the content of Slovakia and Hungary's complaints against relocation decisions. The article summarizes conclusions and recommendations on the management of the migration crisis.

Key words: Immigration, immigrants, immigration crisis, refugees, Geneva Convention on Refugees, European Union, Area of Freedom, Security and Justice, relocation, resettlement, asylum, Common European Asylum System 